\title{
Moral Religiosities: How Morality Structures Religious Understandings during the Transition to Adulthood
}

Published in Sociology of Religion

\author{
Michael Rotolo* \\ University of Notre Dame
}

\begin{abstract}
Religiosity remains an important sociological concept, from assessing religion's effects on various outcomes to describing large-scale religious change. And yet conceptualizing religiosity - as a measure of intensity of religious practice - requires accounting for how respondents understand religious practice. Drawing on four waves of longitudinal interview data from the National Study of Youth and Religion (NSYR), this paper examines the religious understandings of young Americans as they develop over 10 years. I find that respondents' religious understandings are shaped by deeper moral orientations that broadly structure their lives. From these moral orientations, I theorize four ideal types of religious practitioners that help explain complex patterns of religiosity in America - the Congregant, the Believer, the Spiritualist, and the Metaphysician. Recognizing the moral orders that structure young Americans' religious understandings opens new pathways for theorizing religion's influence and change over time.
\end{abstract}

Keywords: religiosity, emerging adulthood, morality, reflexivity, life course

\footnotetext{
* Department of Sociology

4060 Jenkins Nanovic Hall

Notre Dame, IN 46556

Email: mrotolo1@,nd.edu
} 


\section{INTRODUCTION}

Scholarship in many fields illustrates the theoretical significance of "religiosity" - the widespread neologism implying a measurable scale of religious intensity. Despite the various and sometimes ambiguous ways it is conceptualized, religiosity has been linked to health and wellbeing (Blanchard et al. 2008; Hackney and Sanders 2003; Huijts and Kraaykamp 2011), prosocial behaviors and civic engagement (Ellison 1992; Lam 2002; Park and Smith 2000; Wuthnow 1991), and numerous other areas of interest. For many studies, it is considered an essential, albeit "clunky," variable.

While some surveys and polls still reduce religiosity to "frequency of church attendance," the sociology of religion has contested and refined conceptualizations of religiosity for roughly six decades (Fukuyama 1961; Glock 1959). Though early conceptualizations were largely theoretical and correlational (Allport and Ross 1967; Glock and Stark 1965; Lenski 1963), recent work draws on advanced statistical techniques — like cluster analysis and latent class analysis_to uncover various patterns of religiosity (Bravo et al. 2016; Pearce et al. 2013; Storm 2009). These studies identify important patterns of religious practice that are not empirically obvious.

Though methods for studying religiosity are increasingly sophisticated, little work has systematically investigated respondents' own conceptualizations of religiosity. We know little about how they understand their religiosity in their own terms, why they understand it that way, and how it connects to larger moral or cognitive frameworks. While one person may attend church four times annually due to negligible religious commitment, a highly religious person may attend the same amount due to work or other constraints. Still another person may not see church attendance as important to their religiosity. Some even see it as counterintuitive for real religious engagement. In my data, these sorts of realities are the rule. 
Studies that conceptualize religiosity also tend to rely on survey responses, most of which require respondents to choose from narrow scales of traditional, Christocentric religious practices that may not be compatible with their own religious conceptions. What we know is not how respondents understand their religious practice, but rather how respondents' normative religious practices measure up to our scholarly categories and constructs. Their religiosities are deduced, not emergent.

Several works acknowledge the complexity of religiosity, documenting the unique ways it is lived out in everyday life (Ammerman 2007; Bender 2003; Hall 1997; McGuire 2008). People's "lived religion" includes not only formal religious engagement, but also how and what people eat, how they dress, how they deal with birth and death and sexuality and nature, even how they modify hair and body through tattoos or dreadlocks...the space people inhabit...and other folk or community traditions that enact a spiritual sense of solidarity and transcendence (Ammerman 2014:190$1)$.

The lived religion perspective illuminates that people's actual religious lives are not "neatly contained in binary categories of organized v. individual, religious v. spiritual, theistic and transcendent v. nontheistic and immanent" (Ammerman 2013:275).

Likewise, "each person's religious practices and the stories they use to make sense of their lives are continually adapting, expanding or receding, and ever changing” (McGuire 2008:210). How people understand and relate to religion is fluid and dynamic. Ammerman (2013:276) concludes, "Our categories of analysis need to encompass the large areas of overlap, but they also simply need to be redrawn." And McGuire (2008:210) asks, "How can we find a 
way to think about religious belonging and commitment that enables us to consider the lived religions of such diverse individuals?"

I argue that a focus on morality offers a productive path forward. While religiosity is complex and ever-changing, the range of people's conceivable religious understandings is grounded in certain frames and "moral orders," which exist interpersonally at communal and societal levels (Smith 2003; Wuthnow 1987). Better understanding religiosity, then, is not simply about identifying frequencies and patterns of common religious practices, which overlooks the meanings of those practices and inevitably excludes other forms of religious engagement. Rather, it involves identifying the moral frameworks and assumptions that guide people's engagement with religion in the first place and which consequently affect their religious practices.

In this paper, I qualitatively investigate the religious understandings of young Americans as they develop over 10 years using longitudinal interview data from the National Study of Youth and Religion (NSYR). I find that respondents' religious understandings vary according to their orientation along two moral spectrums: "following the way" versus "making the way" and "helping self" versus "helping others." From these moral spectrums, I theorize four ideal types of religious practitioners that help explain complex patterns of religiosity among young people in America. I conclude by discussing the implications of these findings for studying religiosity, religious and nonreligious identities, and religious change.

\section{THE MORAL ROOTS OF RELIGION}

Durkheim (2001[1915]:46) insisted that religion is "eminently collective" and consists of "beliefs and practices relative to sacred things, that is to say, things set apart and surrounded by prohibitions — beliefs and practices that unite its adherents in a single moral community." He claimed, "Religious forces... are moral powers since they are wholly constructed from the 
feelings the collective moral being arouses in those other moral beings, the individuals." (2001[1915]:168). For Durkheim (2001[1915]:314), "religious forces... are human forces, moral forces." And yet, in studies today, morality is more likely to be examined as a byproduct of religion than its source.

One need not accept Durkheim's reductionist claim that religion is nothing but a mirror of society to accept his broader idea that religion is rooted in moral orders. Several philosophers and social theorists acknowledge the fundamental role of moral orders in directing human social life (MacIntyre 1984; Smith 2003; Taylor 1989; Wuthnow 1987). By “moral order” they generally refer to "an interpersonally...shared structure of moral beliefs, desires, feelings, and boundaries that are derived from larger narratives and rituals" of society or specific groups (Farrell 2015:10). These moral orders implicitly and explicitly specify what is good and bad, right and wrong, higher and lower, just and unjust, and worthy and unworthy (Smith 2003; Taylor 1989), and they "tell us most fundamentally who we are, why we are, what we should do, and why it all matters" (Farrell 2015:3). Smith (2003) and Taylor (1989) claim that thinking in terms of moral classifications is a distinct and inescapable part of human nature: "we cannot but orient ourselves to the good, and thus determine our place relative to it" (Taylor 1989:52).

Moral orders can be formal and institutionalized, such as the moral orders of religious traditions, corporations, or universities. For example, Smith (2003:16-7) describes religious liturgies as fundamentally enacting moral orders: "Liturgy ritually reenacts a tradition, an experience, a history, a worldview." However, moral orders can also be informal and largely implicit, such as notions about what is "decent" or moral orders that guide behavior in particular social settings, like a classroom, a fraternity party, or a gala. Wuthnow (1987) and Smith (2003) 
both connect the influence of moral orders to the dramaturgical sociological perspective and social rules about how people are "supposed to" behave (Garfinkel 1984; Goffman 1959).

The various moral orders of society deeply influence how people understand, participate in, and relate themselves to religion. Whether attending church weekly, lighting a candle, meditating, sharing a meal, getting a tattoo, protesting, or participating in other religious practices, people enact and sustain moral orders. Whether taking pride in a religious community or rejecting it, people act in relation to particular moral orders. When people's religious participation changes over time, due to their beliefs about the truth of religion, their feelings toward organized religion, or even their prioritization of other ways to spend their time, they are acting in accordance with moral orders.

In discussing the challenges of capturing people's lived religiosity, Ammerman (2007:13) claims, "We need to take seriously both the ability of institutions to produce and enforce patterns of meaning and action and the ability of individuals and collectives to improvise and sustain alternatives. That is, we take both structure and agency as essential elements in any explanation for whether and how religion is present." Focusing on morality can preserve the complexities of individual religious agency and creativity, while simultaneously identifying the shared rules, expectations, and commitments that guide those choices and behaviors. By examining moral frameworks, we can better understand the organizing principles that guide people's diverse and ever-changing religious engagement.

\section{DATA AND METHODS}

My analysis focuses on longitudinal interview data from the 2002-2012 NSYR. Specifically, I analyze the responses of 86 young people who completed both interviews and surveys during all four waves, from ages 13-18 until ages 23-28. To maximize diversity and get a 
broader landscape of religiosity during the final wave, I also analyze an additional 201 respondents who completed both interviews and surveys in Wave 4. Though not nationally representative, the demographics of the 287 Wave 4 respondents parallel census data on gender, race, region, and religious tradition.

I focus on these data for two primary reasons. First, studying interviews with the same 86 respondents over 10 years offers great depth into the complexities of their religious understandings, as well as the contexts and life experiences that shape them. Relatedly, the longitudinal aspect of the interviews clearly indicates the persistence of the moral framework I identify over time. Even as respondents' specific orientations to religion changed over time, they still discussed it within the same overarching moral framework.

Second, the NSYR data captures the stage of life theorized as "emerging adulthood," in which young Americans typically gain independence, decide their beliefs and values, and accept responsibility for their actions (Arnett 2001). During this period, respondents are actively working out their own beliefs and identities by grappling with the various possibilities that confront them. This 10-year period captures significant changes in respondents' lives broadly (e.g. going to college), variation in their moral orientations, as well as resultant change in their religious engagement. The variability of this life stage helps illuminate the mechanisms at work. Focusing on young people also enables identification of "newer" religiosities that may exist.

I coded the interviews abductively, which involves iterative movement between data and theory (Danermark et al. 2002; Peirce 1934; Timmermans and Tavory 2012). Abduction can also be described as "recontextualization," in which a phenomenon is constantly reinterpreted in light of different frames in hopes of gaining new meaning and explanatory clarity (Danermark et al. 2002). In practice, my coding was similar to inductive coding but was constantly refined by 
considering existing theories of religiosity, as well as scholarly work on moral frameworks and worldviews, which I discuss in the Findings section. I began by simply coding everything that explicitly or implicitly denoted moral classification (i.e. good/bad, right/wrong, just/unjust, worthy/unworthy, etc.). Over time, clear patterns emerged in how respondents morally classified the matters they discussed. The abduction process concludes with the related process of retroduction - asking, "What must be real and operative, even if it is not observable, in order to explain the events we observe?" (Smith 2010:15). In the case of my analysis, retroduction led to the moral spectrums I identify below.

I also used a case-based logic (Burawoy 1998; Small 2009; Steinmetz 2004). Each respondent with four waves of interview data was a case, and I analyzed them with careful consideration of their specific context and life experiences. After considering the particularities of each case, I extracted general explanatory mechanisms (Spillman 2014). A case-based logic differs from the positivist demands of quantitative analyses. Instead of aiming for representativeness, I aimed for saturation, in which adding new cases offered very little new or surprising information (Small 2009). All respondent names are pseudonyms that I applied.

\section{FINDINGS}

In analyzing respondents' religious understandings over 10 years, I identify two highly influential moral spectrums shaping their dispositions. Together, these spectrums compose a "moral framework" related to various "moral orders" in society, but I label them as "moral spectrums" because respondents specifically conceptualize them as spectrums with opposing ends in their deliberation. Thus, these spectrums emerge from the data. As respondents deliberate about their values, interests, goals, and challenges, these moral spectrums serve as a pervasive framework for both religion and other areas of life. I find that respondents generally care about 
all four "goods" at the ends of these two spectrums, but fall in different places along each spectrum, based on various aspects of their context, background, and personal experiences. Following or Making the Way

The first moral spectrum can be summed up in respondents' own words as whether they will "follow the way" or "make the way." This concern involves respondents' reflexivity about whether they will follow tradition, be embedded in structures, and adhere to shared norms or instead carve their own path and run with their own (perceived) independent, free, non-coerced, autonomous agency. In the context of religion, this spectrum corresponds to involvement in organized religion, adherence to a particular religious tradition, perceptions about the historicity and fallibility of religious scriptures, and resistance toward being forced in any way. However, in respondents' lives broadly, it also involves dispositions toward capitalist bureaucracies, abstract conceptions of national unity, power structures embedded in history, and so on. Table 1 below provides some additional interview discourse conveying this moral spectrum.

\begin{tabular}{|r|l|}
\hline Follow the way & Make the way \\
\hline Am I doing what I'm supposed to? & Am I being forced? \\
Adherence to tradition & Openness to new ways \\
Black and white & Gray \\
Set & Changing/wide open \\
Embedded & Removed \\
I should/ought & I don't have to \\
What others think & What I think and feel \\
Do what's right & Do what you want/whatever floats your boat \\
Devoted & Take what you want/pick and choose \\
Certainty & Freedom/liberty \\
We believe... & To each their own \\
It's wrong & I don't want to judge \\
Belonging & Dealing with own stuff \\
This is true & This is just stuff/content that can't be proved \\
Common goal & Unique concerns \\
Old-fashioned & Changing times \\
Responsibility/obligation/pressure & Wild partying kind of crowd \\
Settled down kind of crowd & Whing \\
\hline
\end{tabular}

Table 1: Interview Language Related to Following vs. Making the Way 


\section{Helping Yourself or Others}

The second moral spectrum framing respondents' religious understandings involves whether they will "help themselves" (and their in-groups) or "help others." As respondents figure out how to spend their time and where meaning is found in life, how they attune themselves toward their own needs versus others' needs matters significantly. This spectrum is also commonly conceptualized as an inward versus outward orientation, or an individualist versus collectivist concern. Table 2 provides some of the language indicating the existence of this moral spectrum guiding respondents' thoughts.

\begin{tabular}{|r|l|}
\hline Help self & Help others \\
\hline Help my own & Help the world \\
Get & Give \\
Step over people/Don't get stepped on & Walking together \\
Better self & Better society \\
Make myself happy & Make others happy \\
Taking care of me and mine & Taking care of everybody \\
Taking care of home & Going out and helping the world \\
Taking advantage of situation/Getting ahead & Giving back \\
Focus on the inside & Focus on the outside \\
Others rubbing off on you & Rubbing off on others \\
\hline
\end{tabular}

\section{Table 2: Interview Language Related to Helping Self vs. Helping Others}

Both of these spectrums resonate with other scholarly work on morality, worldviews, and values, which lends support to their existence and influence in society. For example, the "follow the way" versus "make the way" spectrum parallels Hunter's (1991) orthodox versus progressivist worldviews, Bellah et al.'s (1985) traditional versus individualist types, and Archer's (2007) communicative versus autonomous reflexive types. Haidt's (2012) Loyalty, Authority, Sanctity, and Liberty moral foundations map onto "following" versus "making the way," while his Care and Fairness moral foundations resonate with "helping self" versus "helping others." Together, the spectrums I identify most closely parallel the dimensions of motivation identified by Schwartz's (1992) inventory of values: conservation versus openness to 
change, and self-enhancement versus self-transcendence. However, I uniquely derive these spectrums by studying emerging patterns in respondents' understandings as they develop over 10 years, rather than inferring them from questionnaire responses.

\section{Changing Moral Orientations, Changing Religiosities}

To illustrate the influence of these moral spectrums, I describe the religious development of Jake, a middle-class white Baptist from North Carolina, whose survey religiosity measures hardly change over the 10 years of the study. He consistently reports a Baptist identity, regular church attendance, a high importance of faith, and being very close to God. His interviews suggest a different story.

In Waves 1 and 2, when Jake was 14 and 16 years old, he demonstrates a strong orientation toward "following the way." His perspective toward "helping self" versus "helping others" is fairly balanced. Jakes describes going to church weekly and claims, "If you're gonna be a Christian, [you] need to believe the whole of Christian teachings. [If you don't,] you're not really a Christian, because you have to believe in everything." When asked about incorporating practices from other religions, he says, "I think that's completely stupid because it's kind of cheating on both religions...you're kind of a hypocrite." During these two waves, while Jake is still a teenager living at home with his parents, Jake strictly follows his religious tradition and insists, "One religion is really true [and] you can't pick whatever you want."

By Waves 3 and 4, when Jake is 19 and 25, things change drastically. After being completely let down by his parents, not being able to attend college, and now working in a grocery store, Jake breaks from "following" in favor of "making the way," and strongly emphasizes "helping others." Jake now describes his religious background saying, "I grew up in a Southern Baptist church...very right-wing, kind of strict." He claims, "I do consider myself 
religious" and "I was raised to always do the right thing and raised in a church — it kinda does sculpt you, I guess, when it comes to morally." However, he now claims that he does not attend church at all, does not have a religious affiliation, and says, "I think I'm very spiritual" and "everyone should decide [their beliefs] for themselves." Jake describes his religion as a basic "philosophy" of "what would Jesus do," and argues, "All religions...have the basic point of doing the right thing...you take care of others." While the quantity of Jake's religiosity appears constant on the survey, both the quantity and quality change drastically in his own descriptions.

On the other hand, Cassidy, an upper-class Catholic from Massachusetts, shows a pattern of steady decline on the religious survey measures over 10 years. At age 15, she attends Mass weekly, prays a few times a week, and reports that her faith is very important. By age 26 , she identifies as nonreligious, never attends church, and reports that faith is not very important.

Despite this pattern of fallout on the survey, Cassidy's interview deliberations paint a different picture. From Wave 1, she demonstrates a strong preference for "making the way" and "helping self." She was never into "following the way." In relation to the Catholic practices she was required to participate in at Wave 1, she says, "I think I go through the actions but I think like...the faith is kind of missing." Based on her parents' different religious backgrounds, she never felt expected to be religious, and says, "I don't think anybody should be forced into a religion." When asked more specifically about her beliefs, she claims, "I admit there is a God...but I don't think I'm being like judged or whatever...like I do what I'm gonna do...if he doesn't like it...I don't really think about that."

Cassidy"s orientation toward "making the way" and "helping self" remains constant over 10 years. However, despite her decline in religiosity on the survey, her interview responses convey that she has become significantly more spiritual over time. In Wave 4, she works for a 
nonprofit and has "started a regular yoga practice." Despite identifying as nonreligious on the survey, she admits, "I think I still have some parts rooted in [Catholicism]...but I identify more with I think Buddhism.” Spirituality, rebirth, karma, and alternative medicines are all important to Cassidy in Wave 4, and she says, "It's important to me that I find a yoga community here because, you know, I do see that there's that fulfillment from the spiritual side." She concludes, "I guess having the knowledge that spirituality is part of being a whole person is what I believe." By age 26, Cassidy is unquestionably the most spiritual she has been in her life.

\section{Four Ideal Types of Religiosity}

While my primary focus is on the two moral spectrums identified above as an explanatory framework that tacitly structures religious understandings, I find that dominant orientations along each spectrum correspond to similar types of religious dispositions and reasoning. Thus, in considering these two spectrums together, I theorize four ideal types of religiosity that help explain patterns of religious understandings among young Americans. Figure 1 below visualizes these four types, as well as their percentages in my sample of 287 young Americans from Wave 4. It is important to keep in mind that respondents' specific positions along these spectrums vary and often change over time. 


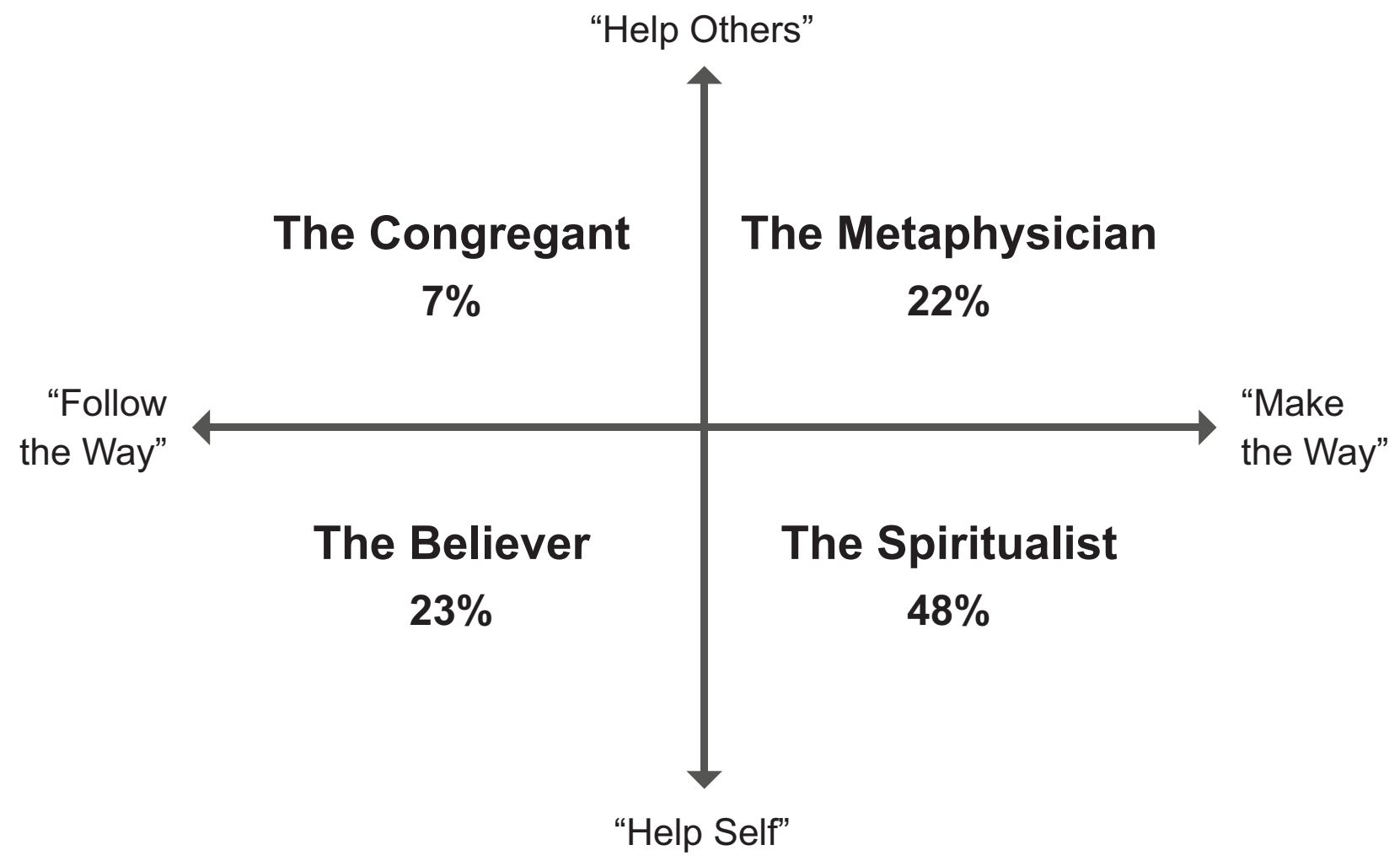

Figure 1: Four Ideal Types of Religiosity and Relative Percentages Based on Respondents' Moral Orientations During Wave 4 at ages 23-28. $N=287$

\section{The Congregant}

The Congregant represents those who are dominantly oriented toward "following the way" and "helping others." These respondents typically adhere to a religious tradition and have a sincere concern about those beyond their in-groups and self-interests. Congregants' religious practice is most similar to how religiosity is usually conceptualized in sociology, including elements like religious service attendance, regular prayer, and belief in the importance of faith (e.g., Norris and Inglehart 2004; Schwadel 2011; Voas and Chaves 2016). They are also the smallest religious type in Wave 4 by a significant margin. This type crosscuts all religious traditions. However, $41 \%$ of black Protestants fell in this category, making it the largest type among black Protestants. Black respondents often allude to their churches' important role in structuring and helping out their larger community (Lincoln and Mamiya 1990). 
Congregants usually participate in the activities of organized religious communities, and they admire or are proud of their religious communities. Involvement is a key part of the Congregant's religiosity, similar to Wuthnow's (1998) "dweller" category. In addition to regular religious service attendance, Congregants' religious involvement often includes scriptural studies, choirs, or other church activities. They also have a strong focus on service to others and "practicing what you preach," which tends to involve helping their larger communities. Respondents mention service projects like helping at soup kitchens, raking the yards of the elderly, and service trips to areas impacted by poverty or national disasters.

When asked open-endedly to describe himself in terms of his religion, David, a 26-yearold black Baptist man from South Carolina, said, "I'm getting to know it a little better now being in church basically every Sunday, going to prayer meeting, and stuff like that...My church, you know, the name of it means you have to help - what your church stands on is to help other people, and so we do a lot of that." He continued, "Two Sundays, I'm actually participating in the choir. The other two is just, you know, church...If you're involved, people want to see you...You want to come out and represent." David goes on to describe coming to church, paying tithes, visiting people in the hospital, cutting grass for the sick, building a community softball field, and other activities as "things we're supposed to do."

Claire, a 25-year-old white woman from Colorado, attends a non-denominational Christian church twice a week but emphasizes, "If you sincerely want to change your ways, it's really important to live what you say because if you really believe it, then won't you live that way?" Claire is a life-long church attender, has participated in numerous religious trips and camps, and identifies her grandmother as the greatest influence on her religion. She claims that 
maintaining her faith is "easy overall, but easier when you're in a community and the things that you do are fun.” When asked about the religion of young people today, she says,

I think religion is specifically tough for Americans because we're so individualistic, we want to be ourselves, and we want to do our own thing. And they see coming to a church as going through a factory and coming out looking the same, which is what a lot of churches have done, you know, with good intentions.

She continues, "But ideally, the church should raise you up according to how God has made you, pull out your best qualities, and unify you toward the same purpose."

For both David and Claire, being involved in a religious community and helping others are fundamental parts of religious engagement. They are what you are supposed to do. Claire even acknowledges the popular alternative of being individualistic. A defining reason for this orientation is Congregants' general stability in life. Many Congregants either have never left their hometown, have come back to it, or have established firm roots in a new location. All of them have belonged to the same religious tradition their entire lives. Their moral orientation toward "following the way" ties to having a "religious home," as well as positive experiences that outweigh their negative ones. That is, Congregants are not oblivious to the potential threats and negative consequences of rigid structures, but rather ultimately see "more good than harm."

Interviews from Waves 1 and 2 indicate that many respondents were raised with the traditional religiosity of the Congregant. However, during Waves 3 and 4 when respondents were between the ages of 18 and 28, most developed an orientation primarily toward "making the way" and/or "helping self" as they sought to establish themselves in the world. Given the unique opportunities and challenges of this stage of life, the religious model of the Congregant is often 
less viable or desirable. Many respondents explained that when they left home for college or work, they struggled to find a religious community similar to the one they grew up in. Likewise, many expressed the sentiment of a respondent who said, "[Church] is just not in my life right now. I can totally see it like, as I get older, me being in it. But right now...part of it is I just want to sleep in on Sunday." In general, the religiosity of the Congregant is not only uncommon among young adults. It is not even understood as something they should have.

\section{The Believer}

Like the Congregant, the Believer is primarily oriented toward "following the way." However, the Believer expresses a stronger orientation toward "helping themselves" and their ingroups than others. For this religious type, believing, having the right beliefs, and adhering to those beliefs is most important. Often, these beliefs involve moral teachings, and sometimes they correspond with "the prosperity gospel" and gaining blessings, hence the focus on self. Smith's (1998) "embattled evangelicals" reflect this religious type. This group resembles depictions of the Religious Right (Braunstein and Taylor 2017; Young 2015). Recent work on Christian Nationalism also describes characteristics similar to this type, namely its emphasis on preserving and believing in a very particular tradition and excluding other cultures (Whitehead et al. 2018).

Believers quickly describe their religious identity in terms of "beliefs" without any prompting of language. Often, they reference specific doctrines that define them (e.g. The Trinity, Salvation) even when they struggle to describe those doctrines in detail. Believers may be involved in a religious community, but they prioritize their personal relationship with God over routine religious involvement. "Sin," "purity," "God's law," "commandments," and "values" are also key parts of their religious identity as they discuss the importance of proper behavior. As one respondent described his religion: "I would say [it's about] having just like a 
personal relationship with God...and like doing what your religion says...like not just going through the paces.” Another respondent explained, “I guess really: Jesus is...I don't know...He's the Son of God. Just as long as you worship him and pray, I guess he'll be there for ya."

Believers are the most likely type to say they have experienced a miracle. They tend to pray for goodness in their lives and sometimes for moral or political issues (e.g. more Supreme Court Justices with conservative views). They often express an aversion to things like "spirituality" and "meditation," portraying them as non-committal (and further indicating the existence of a moral spectrum of "following" versus "making the way"). While some express a positive concern for helping others, it is usually qualified by the more central concern of "converting" others into their religion. "Strongly agreeing" or "strongly disagreeing" on survey questions about religion and morality is also a distinct characteristic of Believers (e.g. moral relativism, respect for religion, whether premarital sex is okay). Seventy-three percent of Mormons and 58\% of Evangelical Protestants fell in this category. Even though some Believers identified as Jewish, Other, or Not Religious on the survey, all expressed primarily Christian beliefs.

Believers tend to have rich conceptions of the afterlife and see belief in God or particular doctrines as the necessary and sufficient condition for avoiding eternal damnation. Describing their religious and moral beliefs often evokes strong emotions. For many, the salience of their beliefs comes from hardship they have faced in life and a conviction to take care of themselves and "their own." The incomes of Believers are lower than those of the other categories, and they have the lowest education attainment with only $23 \%$ obtaining a Bachelor's degree or higher. Those of higher socioeconomic statuses in this category often found their way into a close-knit 
community of believers through conversion or "small groups." Others simply grew up with conservative social and economic views, which this type of religiosity enables and supports.

One example of a Believer is Brandon, a 27-year-old white man from Ohio who attends an Assemblies of God church. When asked open-endedly to describe his religion, he says, "I believe. I follow Jesus. That's how I'd sum it up first and foremost." He describes his denomination as "the one I agree with most wholeheartedly, you know, that I think lines up with scripture." He continues, "I'd say, doctrinally, I agree with everything that they've put out." When asked about his specific beliefs, Brandon claims, “Those who, uh, haven't repented of sin and come to faith in Christ ultimately are rejecting his offer of salvation, what he's done on the cross, so therefore are condemning themselves to hell." He also says he has become "more religious" by explaining, "I've grown deeper in my convictions, deeper in my knowledge, understanding of what God's work said," which gives more insight into how he understands religiosity. For Brandon, belief in the form of adherence is defining of religiosity.

Megan, a 27-year-old white Mormon woman from Indiana, describes her religion as "definitely not perfect, but I definitely try hard." She describes her specific tradition saying, "Well, I personally believe that it is truly Christ's church on the Earth. I think all other religions have definitely some good parts, but I feel like, um...like, it is Christ's church, and, uh, that we have the authority from him." Megan describes the importance of personal revelation in depth, claiming, "You can pray about something... and Heavenly Father can speak to you through the Holy Ghost and teach you things. Or pray about a decision, he'll help you know what decision is the most correct choice. Or even like feelings of warning. Or of comfort. I feel like that's personal revelation from him.” The themes of following and self-support are apparent in Megan's descriptions. 
While Brandon and Megan come from very different backgrounds, how they understand and practice their religion is similarly rooted in a deep commitment to the doctrines of their religious tradition, personal relationship with God, and a self-oriented focus on spiritual growth, blessings, and salvation. Strictly following what they have been taught and actively believing are things they should do as proper and commendable religious engagement.

\section{The Spiritualist}

The third and largest religious type in my sample is the Spiritualist, ${ }^{1}$ which includes those dominantly oriented toward "making the way" and "helping themselves." Fifty percent of this group identifies as "nonreligious" on the survey, and 50\% express a religious affiliation. However, they all express similar dispositions related to religious practice, which involve negotiating personal meaning from among the many beliefs, ideas, and symbols in society.

Like Wuthnow’s (1998:50) “seeker” religious type, Spiritualists are “content with ambiguity, provisional truths, and practical wisdom that suits everyday needs." They resonate with the description of religious people in Taylor's (2007:507) A Secular Age, "seeking a kind of unity and wholeness of the self, a reclaiming of the place of feeling, against the one-sided preeminence of reason, and a reclaiming of the body and its pleasures from the inferior and often guilt-ridden place it has been allowed in the disciplined, instrumental identity." As Taylor (2007:507) notes, "The search for spiritual wholeness is often closely related to the search for health," and thus the religiosity of the Spiritualist often involves elements of self-help, selfimprovement, and acknowledging self-worth.

\footnotetext{
${ }^{1}$ This type should not be confused with the Spiritualism movement of the nineteenth and twentieth centuries (Moore 1977; Weisberg 2004) or Spiritualist churches.
} 
Because they are oriented toward "making the way," Spiritualists understand their religious beliefs and practices as something you can pick and choose as you please. Their religiosity parallels the "Sheilaism" described in Habits of the Heart (Bellah et al. 1985), and one respondent even described their personalized religion by similarly using their name. In unique ways, Spiritualists all assemble various beliefs and practices related to religious ideas, similar to the "spiritual but not religious" interviewees in Belief without Borders (Mercadante 2014). Thus, even though half self-identify as "nonreligious" on the survey, the way they actually depict their religious and spiritual views when allowed to elaborate suggests the presence of a particularthough not always labeled - type of religiosity.

Though some Spiritualists claim a religious affiliation, they are often hesitant about being perceived as "too religious," which they associate with being "fanatical," "judgmental" or "brainwashed." The explicitly "nonreligious" express a similar moral aversion to "following the way," and thus "non-religious identities can be just as dogmatic and certainty-filled as religious ones" (Frost 2019:836). Because of the fluidity and permeability of religious, spiritual, and nonreligious boundaries (Ammerman 2007, 2013; McGuire 2008; Woodhead 2017), as well as the stated religious and spiritual practices of the "nonreligious," I classify them as a part of this religious type, rather than assuming that they are completely free from the influence of the religious beliefs, practices, rituals, ideologies, embodied experiences, memories, symbols, and materials that pervade American society. I expand on this in the Discussion section below.

Many Spiritualists grew up either with no religion or only a nominal religious affiliation handed down by their parents. Some expressed that work schedules, moves across the country, or other commitments have simply made being religiously committed a greater challenge. Other Spiritualists struggle to understand, make sense of, or believe in God. In this case, their 
religiosity resembles "fuzzy fidelity" or the loose, casual religious connection described by Voas (2009). However, the most common reason for Spiritualists' disengagement with organized religion is the actions of religious organizations. Many Spiritualists have felt excluded by religious communities or know others who have. On the survey, $68 \%$ saw religious adherents as too judgmental of other people. And others describe the many ways religion has been used by those in power to manipulate others. Spiritualists are highly sensitive to any type of "force" that may compromise personal autonomy and freedom to make decisions on one's own.

Jade, a 26-year-old black woman from New York, described herself religiously saying, "I believe in God, but I don't believe that you need to go to church and all that in order to sustain a relationship with God...And then with all the crooked, hypocritical, just disgusting people who are in church — that just kind of makes it hard for me to even want to be there." She continued, "Honestly, if you live in a way that is okay to you, who is God or anybody else to tell you that it's not right? It's just kind of like: if this is what I know and feel like is right for me, how can any higher power or anything else tell me it's not right, or if you're the high power, why would you allow this to go on if it's so wrong?" When asked how easy or hard it has been to be religious, Jade explained, "It's been very easy for the simple fact that I became a person who really doesn't care what people say, think, or feel when it comes to their thoughts and opinions of me because I'm like, 'That's just your opinion'...This is what works for me."

Mark, a 25-year-old white man from Texas, described his religion as: "I'm an atheist, but I'm not gonna like preach it to you. But yea, I mean, I'm passionate about it." He claims, I used to be super Christian, but I just started thinking about it, and I got into science, and...it's a means of controlling people. If you take a step back and you 
honestly look at it, that's exactly what it is. Why else would people say, "Give me all your money, and when you're dead you'll go to a nice place?"

He continued, "You only live once. How are you gonna think like that?" At times, Mark insisted, “I don't believe anything," but later shared, "Buddhism kind of interests me. Just finding your inner peace, that type of thing." When later asked why he believed there was some truth in Eastern religions, Mark said, "Finding your inner peace, finding balance in the world and stuffthat kind makes sense to me. 'Cause they're not out to judge you. They're not out to get anything from you...It's all to make yourself feel better about yourself from the inside out.” He concluded, "I think everyone's goal is to be happy with themselves and comfortable with who they are. And that seems like that's kind of what [Eastern religions] are about.”

Both Jade and Mark identify several interests in and potential benefits of religion as they describe the happy, good lives they are ultimately seeking. However, the rigidity, abuses of power, and closed-mindedness they perceive among organized religions and religious people overshadow formal religious involvement. In addition to $64 \%$ of "Not Religious" respondents falling in this category, $72 \%$ of Catholics and $64 \%$ of Mainline Protestants respondents are Spiritualists.

\section{The Metaphysician}

Finally, the Metaphysician type represents those dominantly oriented toward "making the way" and "helping others." Metaphysicians generally do not feel bound by structures and traditions. However, they do care about "the world," "the big picture," and all that is "out there" beyond their immediate interests and concerns. Those in this category may also identify as religious or nonreligious depending on their unique life experiences, and 51\% claim "Not Religious" on the survey. 
Metaphysicians tend to emphasize a mindfulness of "ultimate things," like gods, as well as morality and purpose in the world. Their religiosity is defined by a particular ethos or philosophy toward the world. Ammerman's (1997) “Golden Rule Christians” and Bender's (2010) "New Metaphysicals" resonate with this ideal type. This type has the highest average education level, with $68 \%$ having a Bachelor's degree or higher. Christians of this type were generally supporters of the Social Gospel and liberation theology. And 55\% of Jews fell in this category. They often described the importance of Shabbat meals and other meals with extended, meaningful conversations, as well as "being Jewish all the time," rather than focusing primarily on rituals and laws.

Metaphysicians spend considerable time pondering reality, existence, and meaning. Even when uncertain, they have a sense of "what it's all about" that impacts their choices and actions in everyday life. They are more likely than Spiritualists to acknowledge the value and contributions of organized religion, and they sometimes participate in religious communities. However, typically, they have been disillusioned by organized religion, either by realizing the arbitrariness of various doctrines, the fallible human interpretation that has shaped religious teachings, or the failure of their basic religious roots to help during unsettled and changing times. Some Metaphysicians who belong to religious communities describe their involvement as more of an opportunity for reform than actual belonging.

In terms of conventional measures of religiosity, Metaphysicians look nearly identical to Spiritualists. This similarity is not surprising, given that those measures are rooted in traditional religious involvement. However, interviews with Metaphysicians show that their dispositions toward religion are very different from Spiritualists. Their religiosity is rooted in existential 
concern and collective impact rather than personal growth. Their moral inclination is to look outward toward others, rather than to focus on their self-advancement and upward mobility.

Taylor, a 28-year-old white man from Pennsylvania, described his religiosity saying, 'I'm kind of like, 'There's an afterlife. There's a higher being.' But I don't really buy into the religious ritual side of it." He continues, "Being a good person and like thinking metaphysically about the impact that I'm going to leave on the world...that's my general approach.” Taylor insists, "There probably is a God, but our minds, while powerful, are still so limited that we can't even wrap our heads around what it is," and "I don't think everybody's relationship with God is the same...If it's 'point A' to 'point F' for me, it might be 'point B' to 'point 4' for you...It's a dynamic thing unique to each person." Taylor now attends a "home church," describing it as "a community of really nice people where I go and think about things metaphysically and maybe have a beer afterwards." He describes his commitment as "trying to apply my logic, reason, faith, rhetoric — whatever you want to say — to an unsolvable problem."

When asked about her religion, Becca, a 26-year-old Jewish woman from New York, described herself as "culturally Jewish" and "spiritual but not religious." She explains, "I think all the rituals and symbols are really beautiful, [but] I don't like to have a lot of rules dictating my life and set schedules... Probably because growing up, it was forced down my throat.” Becca says, "I have my own sense of God" and that "there's a mystery... and it's important to be aware of that...just to put things in perspective and keep you humble. Keep you aware of more than yourself or your current situation." She continues, "There's beauty and sorrow... and all these things that are just so powerful and irrational, you know. Like how can people think that everything is just scientific?" Despite their low scores on traditional religiosity measures, Taylor and Becca were among the most knowledgeable and profound thinkers on religious matters. 


\section{DISCUSSION}

Drawing on longitudinal interview data from the NSYR, this paper identifies two moral spectrums that structure young people's deliberation about their lives and specifically their religious engagement over time. I further theorize four ideal type religiosities that emerge from various positions along these moral spectrums. Several prominent approaches to religiosity map onto this typology, which lends support to its embeddedness in society. However, this project organizes these religiosities into an cohesive framework explained by varying moral orientations. These findings have several implications for conceptualizing and measuring religiosity.

\section{Moral Religiosities}

Lived religion perspectives illustrate that there is no singular model from which people's religious practices develop (Ammerman 2007; McGuire 2008). However, they also note, "Although lived religion pertains to the individual, it is not merely subjective. Rather, people construct their religious worlds together, often sharing vivid experiences of that intersubjective reality" (McGuire 2008:12). This paper demonstrates that personal religiosity is inextricably tied to larger, shared moral orientations about what is considered good, right, proper, and worthy.

Martí (2015:11) similarly claims, "Religious reflexivity...involves recognizing the process of maneuvering the broader realm of moral imperatives that confront individuals as they selectively consider how to honor and navigate a variety of core concerns.” In a society characterized by pluralism and unpredictability, individuals are forced to reflexively deliberate about their lives and actively define their ultimate concerns in relation to the varying situations they confront, as opposed to passively accepting normative scripts (Archer 2007). In terms of religion, this means "there arise new religiosities, new imperatives for proper or desired 
religiosity, and new ways of legitimizing religious thoughts, practices, and even larger orientations" (Martí 2015:7).

To better understand the diversity of religious identities and engagement today, we must think of religiosity as a dynamic quality influenced by people's diverse life experiences and the moral frameworks they use to navigate them. This further complexifies how we conceptualize religiosity. However, the moral framework I identify pervades young Americans' reflexivity about religion and overlaps with patterns identified by others on both religiosity and moral worldviews. It identifies a substantive way that the quality of young adults' religiosity differs. Rethinking "Not Religious"

These findings also offer new perspective on the religiosities of the "not religious" or "religious nones." Though $38 \%$ of my Wave 4 sample fell in this survey category, these respondents all expressed some religious beliefs or practices, even when explicitly opposed or indifferent to religion. Thus, the "not religious" category was a poor indicator of actual religious engagement and practice. It told very little itself and was often misleading. Some respondents were unaffiliated simply because they had not yet found a religious community they liked in their current area. Often, it meant that respondents saw affiliation with a religious organization as counterproductive or misguided for religious vitality. In some cases, the "not religious" were the most passionate and knowledgeable about religion. As Woodhead (2017:260) explains, "“No religion' is not a mere negation, a secular subtraction from religion, a normative free-for-all or pure cultural diversity." Rather, it denotes a particular self-positioning, usually in relation to organized religious involvement, and nonreligious identities are still constructed in relation to a larger religious landscape (Sumerau and Cragun 2016). 
Rather than focusing solely on discursive religious labels - particularly the religious/nonreligious binary—scholars of religion should consider the various ways religious and spiritual beliefs, practices, ideologies, memories, experiences, symbols, materials, and spaces intersect with individuals' lives in meaningful ways. This study and others (e.g. Ammerman 2013; Chaves 2011; Taves 2009) show that the boundaries between "religious," "not religious," "secular," "spiritual," and even "agnostic" and "atheist" are permeable, overlapping, and often confused, inconsistent, and indeterminable among respondents. "The varied response to changed societal circumstances does not mean a loss of religion but rather an alternative invocation of it" (Martí 2015:10), and including spirituality, the set apart, the transcendent, and other "special things" (Taves 2009) that relate to "the big picture" often illuminates various ways religion actually permeates people's everyday lives. "Not religious" and "spiritual but not religious" are primarily political descriptors (Ammerman 2014), and they relate to respondents' moral orientation toward "making the way" versus "following the way."

\section{Theorizing Religious Change}

These insights also have significant implications for theorizing and measuring religious change. The reflexive deliberations of each religious type indicate that measures, like religious service attendance and importance of faith, mean very different things for different respondents. Not only would drawing conclusions about secularization be erroneous using only these measures, but also drawing conclusions about individuals' own changing religiosity. The longitudinal nature of this study revealed how some respondents changed religious types over time in light of changing circumstances and consequent changing moral orientations. Focusing on changing levels of religious practices without examining changes in respondents' orientation toward those practices would lead to misguided claims about their levels of religiosity. 
Though this paper does not focus on patterns of longitudinal change in types, the Wave 4 distribution of respondents in different types points to an interesting dynamic about the dominant forms of religiosity practiced among young people today. Only 7\% of young adults demonstrated the Congregant religiosity, which comes closest to how religiosity is most commonly conceptualized in sociology. Nearly half of respondents fell in the Spiritualist type. The shift toward more individualistic, "seeking" forms of faith parallels what many have theorized about the evolving religious landscape in America (e.g. Bellah et al. 1985; Roof 1999; Wuthnow 1998). However, this paper describes this shift in the context of the specific moral framework that produces it, as well as some evidence of the shift in individuals' own development. As respondents entered their emerging adulthood years, they often prioritized "helping themselves" and seeking stability and upward mobility. They also tended to focus on breaking from tradition and "making new ways" of understanding and being in the world.

Many respondents implied that, once they grow older and if they have a stable job and families, they might engage in more formal religious involvement. By Wave 4, some respondents realized that focusing solely on themselves is unfulfilling and shifted in the direction of "helping others." This suggests, at a minimum, that the shift toward individualism is not inevitable. Some respondents' religious grappling eventually led them to the more critical, but also knowledgeable and intentional, religiosity of the Metaphysician. Archer's (2007) work on reflexivity predicts and shows some evidence of a similar shift from a communicative reflexivity, to autonomous reflexivity, and finally to metareflexivity. The moral spectrums I identify at least show how it is possible that a more thoughtful, weighty form of religiosity could emerge, despite current trends.

Among a diverse sample of 287 young Americans, I identify four dominant religious types, which stem from larger moral orientations that guide their lives. These four religiosities 
are a result of respondents' moral reflexive engagement with the world, particularly how they relate to structures and other people. These findings present a new perspective on America's complex religious landscape, as well as religious intensity, affiliation, and change. Respondents are not simply "highly religious" or "hardly religious." Rather, they have questions, concerns, tensions, theories, hunches, rationalizations, traumas, and other complex emotions and thoughts that influence their engagement with religion over time. Better conceptualizing and measuring religiosities requires understanding the moral orientations from which they derive. 


\section{REFERENCES}

Allport, G. W., and J. M. Ross. 1967. "Personal Religious Orientation and Prejudice.” Journal of Personality and Social Psychology 5:432-443.

Ammerman, Nancy T. 1997. "Golden Rule Christianity: Lived Religion in the American Mainstream." Pp. 196-216 in Lived Religion in America: Toward a History of Practice, edited by D. D. Hall. Princeton: Princeton University Press.

Ammerman, Nancy T. 2007. Everyday Religion: Observing Modern Religious Lives. New York: Oxford University Press.

Ammerman, Nancy T. 2013. Sacred Stories, Spiritual Tribes: Finding Religion in Everyday Life. New York: Oxford University Press.

Ammerman, Nancy T. 2014. "Finding Religion in Everyday Life." Sociology of Religion 75:189207.

Archer, Margaret. 2007. Making our Way through the World. Human Reflexivity and Social Mobility. New York: Cambridge University Press.

Arnett, Jeffrey Jensen. 2001. "Conceptions of the Transition to Adulthood: Perspectives from Adolescence Through Midlife." Journal of Adult Development 8:133-143.

Bellah, Robert N., Richard Madsen, William M. Sullivan, Ann Swidler, and Steven M. Tipton. 1985. Habits of the Heart: Individualism and Commitment in American Life. Berkeley: University of California Press.

Bender, Courtney. 2003. Heaven's Kitchen: Living Religion at God's Love We Deliver. Chicago: University of Chicago Press.

Bender, Courtney. 2010. The New Metaphysicals: Spirituality and the American Religious Imagination. Chicago: University of Chicago Press. 
Blanchard, Troy, John Bartkowski, Todd Matthews, and Kent Kerley. 2008. "Faith, Morality, and Mortality: The Ecological Impact of Religion on Population Health." Social Forces $86: 1591-1620$.

Braunstein, Ruth, and Malaena Taylor. 2017. "Is the Tea Party a "Religious" Movement? Religiosity in the Tea Party versus the Religious Right." Sociology of Religion 78:33-59.

Bravo, Adrian J., Matthew R. Pearson, and Leah E. Stevens. 2016. "Making Religiosity Personcentered: A Latent Profile Analysis of Religiosity and Psychological Health Outcomes." Personality and Individual Differences 88:160-69.

Burawoy, Michael. 1998. "The Extended Case Method." Sociological Theory 16:4-33.

Chaves, Mark. 2011. American Religion: Contemporary Trends. Princeton: Princeton University Press.

Danermark, Berth, Mats Ekström, Liselotte Jakobsen, and Jan Ch. Karlsson. 2002. Explaining Society. London: Routledge.

Durkheim, Émile. 2001 [1915]. The Elementary Forms of Religious Life. Oxford: Oxford University Press.

Ellison, Christopher G. 1992. “Are Religious People Nice People? Evidence from the National Survey of Black Americans.” Social Forces 71:411-30.

Farrell, Justin. 2015. The Battle for Yellowstone: Morality and the Sacred Roots of Environmental Conflict. Princeton: Princeton University Press.

Frost, Jacqui. 2019. "Certainty, Uncertainty, or Indifference? Examining Variation in the Identity Narratives of Nonreligious Americans." American Sociological Review 84:828-850.

Fukuyama, Yoshio. 1961. "The Major Dimensions of Church Membership." Review of Religious Research 2:154-161. 
Garfinkel, Harold. 1984. Studies in Ethnomethodology. Oxford: Polity Press.

Glock, Charles. 1959. "The Religious Revival in America?" Pp. 24-42 in Religion and the Face of America, edited by J. Zahn. Berkeley: University of California Press.

Glock, Charles, and Rodney Stark. 1965. Religion and Society in Tension. Chicago: Rand McNally.

Goffman, Erving. 1959. The Presentation of Self in Everyday Life. New York: Anchor Books.

Hackney, Charles H., and Glenn S. Sanders. 2003. "Religiosity and Mental Health: A MetaAnalysis of Recent Studies.” Journal for the Scientific Study of Religion 42:43-55.

Haidt, Jonathan. 2012. The Righteous Mind: Why Good People are Divided by Politics and Religion. New York: Pantheon.

Hall, David D. 1997. Lived Religion in America: Toward a History of Practice. Princeton: Princeton University Press.

Huijts, Tim, and Gerbert Kraaykamp. 2011. "Religious Involvement, Religious Context, and Self-Assessed Health in Europe." Journal of Health and Social Behavior 52:91-106.

Hunter, James Davison. 1991. Culture Wars: The Struggle to Define America. New York: Basic Books.

Lam, Pui-Yan. 2002. “As the Flocks Gather: How Religion Affects Voluntary Association Participation." Journal for the Scientific Study of Religion 41:405-422.

Lenski, Gerhard. 1963. The Religious Factor: A Sociologist's Inquiry. Garden City: Anchor Books.

Lincoln, Eric C., and Lawrence H. Mamiya. 1990. The Black Church in African American Experience. Durham: Duke University Press.

MacIntyre, Alasdair. 1984. After Virtue. Notre Dame: Notre Dame University Press. 
Martí, Gerardo. 2015. "Religious Reflexivity: The Effect of Continual Novelty and Diversity on Individual Religiosity.” Sociology of Religion 76:1-13.

McGuire, Meredith B. 2008. Lived Religion: Faith and Practice in Everyday Life. New York: Oxford University Press.

Mercadante, Linda A. 2014. Belief without Borders: Inside the Minds of the Spiritual But Not Religious. New York: Oxford University Press.

Moore, R. Lawrence. 1977. In Search of White Crows: Spiritualism, Parapsychology, and American Culture. New York: Oxford University Press.

Norris, Pippa, and Ronald Inglehart. 2004. Sacred and Secular. New York: Cambridge University Press.

Park, Jerry Z., and Christian Smith. 2000. “'To Whom Much Has Been Given...’: Religious Capital and Community Voluntarism among Churchgoing Protestants." Journal for the Scientific Study of Religion 39:272-86.

Pearce, Lisa D., E. Michael Foster, and Jessica Halliday Hardie. 2013. “A Person-Centered Examination of Adolescent Religiosity Using Latent Class Analysis." Journal for the Scientific Study of Religion 52:57-79.

Peirce, Charles. 1934. Collected Papers of Charles Sanders Peirce. Vol. 5, Pragmatism and Pragmaticism, edited by C. Hartshorne and P. Weiss. Cambridge, MA: Harvard University Press.

Roof, Wade Clark. 1999. Spiritual Marketplace: Baby Boomers and the Remaking of American Religion. Princeton: Princeton University Press.

Schwadel, Philip. 2011. "Age, Period, and Cohort Effects on Religious Activities and Beliefs." Social Science Research 40:181-92. 
Schwartz, Shalom H. 1992. "Universals in the Content and Structure of Values: Theoretical Advances and Empirical Tests in 20 Countries," Pp. 1-65 in Advances in Experimental Social Psychology Volume 25, edited by M. P. Zanna. San Diego: Elsevier.

Small, Mario Luis. 2009. "How Many Cases Do I Need? On Science and the Logic of Case Selection in Field Based Research.” Ethnography 10:5-38.

Smith, Christian. 1998. American Evangelicalism: Embattled and Thriving. Chicago: University of Chicago Press.

Smith, Christian. 2003. Moral, Believing Animals: Human Personhood and Culture. New York: Oxford University Press.

Smith, Christian. 2010. What is a Person? Rethinking Humanity, Social Life, and Moral Good from the Person Up. Chicago: University of Chicago Press.

Spillman, Lyn. 2014. "Mixed Methods and the Logic of Qualitative Inference." Qualitative Sociology 37:189-205.

Steinmetz, George. 2004. "Odious Comparisons: Incommensurability, the Case Study, and Small Ns in Sociology." Sociological Theory 22:371-400.

Storm, Ingrid. 2009. "Halfway to Heaven: Four Types of Fuzzy Fidelity in Europe.” Journal for the Scientific Study of Religion 48:702-718.

Sumerau, J.E., and Ryan T. Cragun. 2016. “'I Think Some People Need Religion’: The Social Construction of Nonreligious Moral Identities.” Sociology of Religion 77:386-407.

Taves, Ann. 2009. Religious Experience Reconsidered: A Building-Block Approach to the Study of Religion and Other Special Things. Princeton: Princeton University Press.

Taylor, Charles. 1989. Sources of the Self . Cambridge, MA: Harvard University Press.

Taylor, Charles. 2007. A Secular Age. Cambridge, MA: Harvard University Press. 
Timmermans, Stefan, and Iddo Tavory. 2012. “Theory Construction in Qualitative Research: From Grounded Theory to Abductive Analysis." Sociological Theory 30:167-186.

Voas, David. 2009. "The Rise and Fall of Fuzzy Fidelity in Europe.” European Sociological Review 25:155-168.

Voas, David, and Mark Chaves. 2016. "Is the United States a Counterexample to the Secularization Thesis?” American Journal of Sociology 121:1517-1556.

Weisberg, Barbara. 2004. Talking to the Dead: Kate and Maggie Fox and the Rise of Spiritualism. New York: HarperCollins.

Whitehead, Andrew L., Samuel L. Perry, and Joseph O. Baker. 2018. "Make America Christian Again: Christian Nationalism and Voting for Donald Trump in the 2016 Presidential Election." Sociology of Religion 79:147-71.

Woodhead, Linda. 2017. “The Rise of 'No Religion': Towards an Explanation.” Sociology of Religion 78:247-262.

Wuthnow, Robert. 1987. Meaning and Moral Order: Explorations in Cultural Analysis. Berkeley: University of California Press.

Wuthnow, Robert. 1991. Acts of Compassion: Caring for Others and Helping Ourselves. Princeton: Princeton University Press.

Wuthnow, Robert. 1998. After Heaven: Spirituality in America Since the 1950s. Berkeley: University of California Press.

Young, Neil J. 2015. We Gather Together: The Religious Right and the Problem of Interfaith Politics. New York: Oxford University Press. 